\title{
Nutrient matter, fatty acids, in vitro gas production and digestion of herbage and silage quality of yellow sweet clover (Melilotus officinalis L.) at different phenological stages
}

\author{
K. Kara ${ }^{1}$ \\ Erciyes University, Faculty of Veterinary Medicine, Department of Animal Nutrition and Nutritional Diseases, \\ 38280, Kayseri, Turkey
}

KEY WORDS: alpha-linolenic acid, in vitro gas production, malondialdehyde, Melilotus officinalis, silage acidity

Received: 8 February 2021

Revised: $\quad 27$ April 2021

Accepted: 5 May 2021

${ }^{1}$ Corresponding author:

e-mail: karakanber@hotmail.com

\begin{abstract}
Yellow sweet clover (Melilotus officinalis L.) is a legume species, widely used as a forage crop for herbivores. This study aimed to research the nutritional compositions of herbage and silage $M$. officinalis at vegetative, early flowering and full flowering stages. The crude protein (CP) and ash contents of $M$. officinalis herbages and silages in vegetative and early flowering stages were higher than those in the full flowering stage $(P<0.05)$. The linoleic and alpha-linolenic acid percentages in total fatty acids of $M$. officinalis herbages in vegetative and early flowering stages were greater than those in full flowering stage $(P<0.05)$. The neutral and acid detergent fibres without ash contents of $M$. officinalis herbages and silages at the full flowering stage were higher than those of vegetative and early flowering ones $(P<0.05)$. The malondialdehyde (MDA) concentrations (1.12-1.67 $\mathrm{g} / \mathrm{kg} \mathrm{DM})$ of silages were higher than those $(0.38-0.48 \mathrm{~g} / \mathrm{kg} \mathrm{DM})$ of herbages. The in vitro gas production, metabolizable energy, net energy for lactation and organic matter digestibility values and the molarities of volatile acids in fermentation fluid of $M$. officinalis herbages were similar for all phenological stages $(P>0.05)$. The lactic acid contents of silages at vegetative and early flowering stages were higher than that of the full flowering one $(P<0.05)$. The linoleic acid contents of forages were negatively correlated with MDA forage content $(P<0.05)$. Consequently, the values of $\mathrm{CP}$, alpha-linolenic acid and in vitro digestion for herbage, and the nutrient matter compositions of silage, in especially vegetative and early flowering stages, were at non-objectionable levels for quality forage. So, it is suggested that M. officinalis can be used as a good quality silage.
\end{abstract}

\section{Introduction}

Yellow sweet clover (Melilotus officinalis L.) is a legume species that can be widely used as a forage crop worldwide (Ehlert, 2020). Yellow sweet clover is one of the most common species in the Melilotus genus. These species have adapted to environmental constraints such as drought, cold and salinity (Turkington et al., 1978; Al Sherif, 2009).
Yellow sweet clover is used as a ground cover in depleted soils (Allen and Allen, 1981), especially in moderately saline areas where traditional forage legumes cannot be grown (Luo et al., 2014).

Yellow sweet clover develops a root system during the first season, and then produces flowers and seeds during the second season. Second-year yellow sweet clover may appear bushy and reach a height of 1.2-2 m (Klebesadel, 1992; Luo et al., 2014; Cornara et al., 2016). Yellow sweet clover 
is a legume, similar to alfalfa and other clovers; it is reach in crude protein (CP) (about 16-25\% in dry matter (DM)) (Canbolat and Karaman, 2009; Çaçan et al., 2015). Since this forage plant is digested well, it has a satisfactory level of metabolizable energy (ME) (about $10 \mathrm{MJ} / \mathrm{kg} \mathrm{DM}$ for ruminant) as a forage (Canbolat and Karaman, 2009; Ehlert, 2020). It is a good forage source for mule, deer, elk, antelope, and a suitable nesting habitat for pheasants, grouse and other upland birds. Also, sweet clover is extremely attractive to pollinators such as honey bees (Ehlert, 2020). The plant is also mainly known for its anti-inflammatory, antioedematous, spasmolytic, diuretic and sedative properties (Cornara et al., 2016).

The primary concern with sweet clover is the possibility of sweet clover poisoning, which occurs when hay is inadequately allowed to dry or becomes mouldy. Sweet clover contains a substance called coumarin $(0.14-1.14 \%$ in DM) (Luo et al., 2014), which is converted to dicoumarol by fungus in mouldy hay. Dicoumarol is an anti-clotting agent that causes severe haemorrhage in cattle. The conversion of coumarin to dicoumarol can occur even if there is only a little mould in the herbage, so mould level is not a good indicator of the dicoumarol level (Ogle et al., 2008; Ehlert, 2020). The best way to prevent sweet clover poisoning is strict control of silage making or hay curing (Ogle et al., 2008; Ehlert, 2020). Melilotus species, including sweet yellow clover, have not been widely used in forage production due to their high coumarin content. Studies have been carried out to reduce the plant's coumarin level and use it as common roughage (Luo et al., 2014). All Melilotus species, when flowering, have a peculiar sweet odour, which, through drying, becomes more aromatic and more agreeable. The characteristic sweet odour is derived from its coumarins (Jasicka-Misiak et al., 2017). The contamination of all forages and silages with mould fungi often occurs in the field and can also occur during harvesting, transport or storage. However, when they can find a suitable environment (such as moisture and heat in the material), these fungi release their metabolites to the environment. Moreover, poor postharvest management can lead to rapid spoilage. When the DM value drops off below 14\% during the drying phase of forages, it will not be possible for the fungus to multiply and release its metabolites to the environment. Such roughages, prepared under appropriate conditions, will not cause ruminants' health problems (Lacey, 1991; Alonso et al., 2013).
Grazing sweet clover is not problematic because the conversion of coumarin to dicoumarol is impossible without the mould fungus in herbage. The conversion of coumarin to dicoumarol can be prevented by silage making rather than hay as long as the ensiling fermentation process is rapid and complete so that the silage is stable and does not allow mould growth (Ehlert, 2020). We hypotesize that yellow sweet clover can be silaged like other legumes, alfalfa silage, and good quality silage can be obtained (Améndola-Massiotti et al., 2018). Also, that the silage quality and the biochemical/ nutritional compositions of yellow sweet clover may vary at different phenological stages (Ersahince and Kara, 2017; Kara et al., 2018). Little is known about the change of fatty acids and lipid oxidation in silage (Han and Zhou, 2013). Han and Zhou (2013) proved that saturated fatty acids (SFA; C16:0 and C18:0) percentages and malondialdehyde (MDA) concentration of maize silage tended to increase with the ensiling process, whereas unsaturated fatty acids (C18:1, C18:2 and C18:3) tended to decrease. At the same time, the MDA concentration in yellow sweet clover herbage content may increase during ensilaging due to the cell structure deteriorated by crushing at ensilage and during silage fermentation. Another hypothesis is that with increasing MDA in silage, there may be a possible change in the silage's fatty acid profile. This study aimed to explore the nutritional compositions of the herbage and silage of yellow sweet clover harvested at vegetative, early flowering and full flowering stages.

\section{Material and methods}

This study was approved (number: 21/114) by the Local Ethics Committee for Animal Experiments of Erciyes University, Kayseri, Turkey.

\section{The area of yellow sweet clover samples collection}

The yellow sweet clover samples were collected from Kayseri province, located (38 $56^{\prime}$ N, 34 $24^{\prime}$ E) in the centre (Cappadocia district) of Turkey.

\section{Plant samples}

A random sampling method was used from native grassland. The three phenological stages of yellow sweet clover were investigated. Plant samples were gathered in the vegetative $(n=8)$, early flowering $(n=8)$ and full flowering $(n=8)$ stages. The plant samples were gathered from eight different plants for each phenological stage. 
The samples included all aerial parts (leaf, stem or bud-flower) of the plant. Eight samples of yellow sweet clover were randomly collected from four different areas in Kayseri. The sampling amount was about $2 \mathrm{~kg}$ for each replicate and about $16 \mathrm{~kg}$ for each phenological stage. Cutting was manually performed at $1 \mathrm{~cm}$ above the soil. Subsequently, about a 500-g representative sample for each phenological stage was dried in a thermostatically controlled cabinet (Lovibond $^{\mathbb{R}}$, Dortmund, Germany) for $48 \mathrm{~h}$ at $60^{\circ} \mathrm{C}$, and the DM content of herbages was calculated.

\section{Silage of yellow sweet clover}

For each phenological stage, fresh yellow sweet clover samples were manually (with a knife) cut into 2-3 cm pieces. The herbage (about $500 \mathrm{~g}$ ) of yellow sweet clover was ensilaged in a polyethylene $(25 \times 35 \mathrm{~cm}$ sizes) silage bag (Caso-01201, Caso Design, Arnsberg, Germany) and mixed $(n=4)$. These polyethylene size bags were vacuumed using a vacuum machine (Bar Vacuum Sealer, Caso-VC100, Caso Design, Arnsberg, Germany). The silage bags were stored in laboratory conditions in a sun-free environment for 60 days. The silage materials in opened silage bags were dried in a thermostatically controlled cabinet (Lovibond ${ }^{\circledR}$, Dortmund, Germany) for $48 \mathrm{~h}$ at $60^{\circ} \mathrm{C}$, and DM content was calculated.

\section{Determination of the chemical composition of herbages and silages}

Dried yellow sweet clover samples were milled in a grinder mill (IKA Werke, Staufen im Breisgau, Germany) to a maximum particle size of $1 \mathrm{~mm}$. Dry matter, ash, CP (nitrogen $\times$ 6.25) (DK6 Kjeldahl Digestion Unit, Velp Scientifica, Usmate, Italy) and diethyl ether extract (EE) levels (SER 148/3, Velp Scientifica, Usmate, Italy) were determined according to the method reported by the AOAC International (1995). Neutral detergent fibre without ash (NDFom) and acid detergent fibre without ash (ADFom) contents were analysed using a fibre analyser (FIWE3 Fibre Analyzer, Velp Scientifica, Usmate, Italy) according to the methods reported by Van Soest et al. (1991). The NDFom analyses were carried out without amylase. The non-fibrous carbohydrate (NFC) values were calculated according to National Research Centre (NRC, 2001). All analyses were carried out in triplicate.

\section{Determination of malondialdehyde concentration in herbages and silages}

In the analysis, $73.2 \mathrm{mg}$ of 1,1,3,3-tetraethoxypropane (TEP) in a solid form were taken into a tube and dissolved with $10 \mathrm{ml}$ of HCI $(0.1 \mathrm{~N})$.
Test tubes were incubated at $105{ }^{\circ} \mathrm{C}$ for $5 \mathrm{~min}$ and then cooled. This MDA/TEP stock solution $(230 \mu \mathrm{g} / \mathrm{ml})$ was completed to $100 \mathrm{ml}$ volume of distilled water to obtain the stock standard solution (MDA for $23 \mathrm{mg} / 100 \mathrm{ml}$ ). The MDA/TEP standard $(0.024-239 \mu \mathrm{g} / \mathrm{ml}$ MDA/TEP) curve $(\mathrm{f}(\mathrm{x})=$ $\left.0.00972 x+0.1674, R^{2}=0.9929\right)$ was generated using TEP standard. The MDA concentration was given as $\mathrm{mg} / \mathrm{kg}$ DM of forage.

Thiobarbituric acid-reactive substances (TBARS) of samples were determined by the spectrophotometric method reported by Botsoglou et al. (1994). About 2-g dried forage sample was mixed in a tube with $8 \mathrm{ml}$ of trichloroacetic acid (TCA; 5\% in distilled water) and $5 \mathrm{ml}$ of butylated hydroxytoluene (BHT; $0.8 \%$ in hexane). The tubes were vortexed (at $2000 \mathrm{rpm}$ for $30 \mathrm{sec}$.; Velp Scientifica ${ }^{\mathrm{TM}}$ Classic Vortex Mixer, Velp Scientifica, Usmate, Italy) and then centrifuged (at $5000 \mathrm{rpm}$ for $5 \mathrm{~min}$; NF 800R, Nüve, Ankara, Turkey). After centrifugation, the upper hexane layer was removed, and the second layer, the aqueous layer, was pipetted into capped tubes containing $10 \mathrm{ml}$ of $5 \%$ TCA. Later, this $2.5-\mathrm{ml}$ mixture was taken into capped tubes containing $1.5 \mathrm{ml}$ of $0.8 \%$ BHA and incubated for $30 \mathrm{~min}$ at $70{ }^{\circ} \mathrm{C}$. The MDA concentrations of the samples were determined at a wavelength of $535 \mathrm{~nm}$ in a spectrophotometer (UviLine 8100, Xylem Analytics Germany Sales GmbH \& Co. KG, Mainz, Germany).

\section{Determination of fatty acid composition}

The EE residues for herbages and silages of yellow sweet clover were methylated with the threestage modified procedure of Wang et al. (2015), which used $\mathrm{KOH}(10 \mathrm{M})$, methanol, $\mathrm{H}_{2} \mathrm{SO}_{4}(10 \mathrm{M})$. The methylated fatty acids in n-hexane were taken in a vial with PTE caps and analysed in a gas chromatograph (GC, Thermo1300, Thermo Scientific, Waltham, MA, USA) with flame-ionization detection (FID), connected with automatic sampling (Thermo AI 1310, Thermo Scientific, Waltham, MA, USA). The device was equipped with a fatty acid methyl esters (FAME) column (length: $60 \mathrm{~m}$, ID: $0.25 \mathrm{~mm}$, film thickness: $0.25 \mu \mathrm{m}$ and maximum temperature: $250-260{ }^{\circ} \mathrm{C}$ ) and the used parameters were: injection split temperature $255^{\circ} \mathrm{C}$, column temperature $140{ }^{\circ} \mathrm{C}$, and flow rate $30 \mathrm{ml} / \mathrm{min}$ processing method for $42 \mathrm{~min}$. FAME mix (37C) standard solution (CL.40.13093.0001, Chem-Lab, Zedelgem, Belgium) in dichloromethane was used for the identification of peak. Fatty acid identification was performed by comparing the chromatogram peaks with the standard's retention times (Kara, 2020). Polyunsaturated fatty acid (PUFA), monounsatu- 
rated fatty acid (MUFA), medium-chain fatty acids (MCFA) (fatty acids with chains containing from 6 to 12 atoms of C), long-chain fatty acids (LCFA) (fatty acids with chains containing from 14 to 20 atoms of C) and very-long-chain fatty acids (VLCFA) (fatty acids with chains containing above 20 atoms of C) were detected.

\section{Determination of ammonia concentration in silages}

The ammonia concentration in silage fluid was determined using a commercial ammonia assay procedure (Megazyme, K-AMIAR 02/20, Wicklow, Ireland). The $0.10 \mathrm{ml}$ of silage fluid was mixed with $2.0 \mathrm{ml}$ of distilled water, $0.3 \mathrm{ml}$ of buffer plus 2-oxoglutarate and sodium aside $(0.02 \% \mathrm{w} / \mathrm{v})$ and $0.2 \mathrm{ml}$ of NADPH. The absorbance value of the solutions was read at $340 \mathrm{~nm}$ on a UviLine 9100 spectrophotometer (Xylem Analytics Germany Sales $\mathrm{GmbH}$ \& Co. KG, Mainz, Germany). Glutamate dehydrogenase suspension was added to the solution. The absorbance value of the solution was read at $340 \mathrm{~nm}$ on a spectrophotometer (Xylem Analytics Germany Sales GmbH \& Co. KG, Mainz, Germany) again. The ammonia concentration (g/l) was calculated using the formula in the ammonia assay procedure of Megazyme (K-AMIAR 02/20, Wicklow, Ireland).

\section{Determination of acidity values in silages}

The $\mathrm{pH}$ values of opened silages were immediately determined. First, $25 \mathrm{~g}$ of wet yellow sweet clover silage sample was shredded for $15 \mathrm{sec}$ with a laboratory-type blender (Waring Commercial, Torrington, CT, USA) and then shredded for $10 \mathrm{sec}$ with $100 \mathrm{ml}$ of distilled water. The filtered mixture's $\mathrm{pH}$ value was measured with a digital $\mathrm{pH}$ meter (S220 pH/ion meter, Mettler Toledo, Greifensee, Switzerland) (Bernardes et al., 2019). The lactic acid (LA) content in silage fluid was determined according to a modified spectrophotometric method of Barnett (1951) (Tekin and Kara, 2020). The amount of LA in the sample fluid was calculated as lactate equivalent from the calibration curve $\left(\mathrm{R}^{2}=0.95\right)$ of standard lithium lactate $(0.312-160 \mu \mathrm{g} / \mathrm{ml})$. The $\%$ of LA content in silage DM was calculated using the equations as follows:

$$
\begin{gathered}
\mathrm{LA}, \% \text { in DM }=\text { absorbance value } \times 10^{-2} \times \\
(100-\mathrm{DM}) / \mathrm{DM} .
\end{gathered}
$$

The $1.5 \mathrm{ml}$ of silage fluid mixed with $0.3 \mathrm{ml}$ of meta-phosphoric acid $(25 \%, \mathrm{w} / \mathrm{v})$ in a microcentrifuge tube was centrifuged at $15000 \mathrm{rpm}$ for 15 min using a microcentrifuge (Gyrozen 1524, Gyrozen Co. Ltd., Daejeon, South Korea). The supernatant was taken into a gas chromatograph vial. The analysis of organic acids (or volatile fatty acids; VFAs) (acetic (AA), butyric (BA), propionic (PA), iso-butyric (IBA), valeric (VA) and iso-valeric (IVA) acids) in silage fluid was measured by using a gas chromatograph device (GC, Thermo Trace 1300, Thermo Scientific, Waltman, MA, USA) with an auto-sampler (Thermo AI-1310, Thermo Scientific, Waltman, MA, USA) (Ersahince and Kara, 2017). According to the retention time and peak area in chromatograms, the concentrations (mmol/1) of organic acids were identified using a Xcalibur software program (Thermo Scientific, Waltman, MA, USA). The $\%$ concentrations of organic acids in DM of silage were calculated.

\section{Determination of in vitro ruminal digestion and estimated digestion values}

The in vitro digestion potential of the yellow sweet clover herbages at different phenological stages was analysed using an in vitro gas production technique. Rumen fluid, which was used in the in vitro gas production technique (Hohenheim Gas Test), was taken via an oesophageal tube from two Brown Swiss-Simmental mixed breed cattle. The $500 \mathrm{ml}$ was collected from each and mixed. The cattle have consumed the ration, which included maize silage ( $5 \mathrm{~kg} /$ day as fed basis), wheat straw (1.7 kg/day as fed basis), alfalfa herbage (1.5 kg/day as fed basis), sugar beet pulp (4.5 kg/day as fed basis) and concentrated mix feed ( $5 \mathrm{~kg} /$ day as fed basis). The cattle consumed $9.8 \mathrm{~kg} \mathrm{DM} /$ day, which included CP of $1231 \mathrm{~g} /$ day (ruminal degradable protein of $833 \mathrm{~g} /$ day), ME of $24.3 \mathrm{Mcal} /$ day and NDF of $3.95 \mathrm{~kg}$ /day $(40.3 \%$ in ration DM) (National Academies of Sciences, Engineering, and Medicine, 2016). Approximately one litter of rumen fluid was collected in a thermos, which included water, at $39{ }^{\circ} \mathrm{C}$ using $\mathrm{CO}_{2}$ gas, and filtered with six layers of cheesecloth in the laboratory. The samples were incubated in rumen fluid and buffer mix in $100 \mathrm{ml}$ capacity calibrated anaerobic glass fermenter (Fortuna ${ }^{\circledR}$, Poulten \& Graf Ltd., Wertheim, Germany) following the procedures by Menke et al. (1979). One litter of buffer mixture included $474 \mathrm{ml}$ of bi-distilled water, $237.33 \mathrm{ml}$ of macro-mineral solution $\left(5.7 \mathrm{~g}\right.$ of $\mathrm{Na}_{2} \mathrm{HPO}_{4}, 6.2 \mathrm{~g}$ of $\mathrm{KH}_{2} \mathrm{PO}_{4}$ and $0.6 \mathrm{~g}$ of $\mathrm{MgSO}_{4}$ in one litter of bidistilled water), $237.33 \mathrm{ml}$ of buffer solution (35 g of $\mathrm{NaHCO}_{3}$ and $4 \mathrm{~g}$ of $\mathrm{NH}_{4} \mathrm{HCO}_{3}$ in one litter of bi-distilled water), $0.12 \mathrm{ml}$ of trace-mineral solution (13.2 $\mathrm{g}$ of $\mathrm{CaCl}_{2} \cdot 2 \mathrm{H}_{2} \mathrm{O}, 10 \mathrm{~g}$ of $\mathrm{MnCI}_{2} \cdot 4 \mathrm{H}_{2} \mathrm{O}$, $1 \mathrm{~g}$ of $\mathrm{CoCI}_{2} \cdot 6 \mathrm{H}_{2} \mathrm{O}$ and $0.8 \mathrm{~g}$ of $\mathrm{FeCI}_{3} \cdot 6 \mathrm{H}_{2} \mathrm{O}$ in 
$100 \mathrm{ml}$ of bi-distilled water), $1.22 \mathrm{ml}$ of resazurin solution $(0.1 \mathrm{~g}$ of resazurin in $100 \mathrm{ml}$ of bi-distilled water) and $50 \mathrm{ml}$ of reducing solution $(285 \mathrm{mg}$ of $\mathrm{Na}_{2} \mathrm{~S} \cdot 7 \mathrm{H}_{2} \mathrm{O}$ and $4 \mathrm{ml}$ of $1 \mathrm{~N} \mathrm{NaOH}$ in $96 \mathrm{ml}$ of bi-distilled water). The reducing solution was used to provide the oxidation-reduction potential (ORP) and the anoxic conditions. The $\mathrm{pH}$ and ORP of the in vitro digestion fluids were measured using Mettler Toledo InLab ${ }^{\circledR}$ Expert Pro-ISM sensor probes in $\mathrm{pH}$ Ion meter (Seven Compact ${ }^{\mathrm{TM}} \mathrm{pH} /$ Ion S220, MettlerToledo, Schwerzenbach, Switzerland). There was no statistical difference between the in vitro incubation fluids of $\mathrm{pH}$ (6.7-6.85) and ORP values.

The $0.200 \pm 0.010 \mathrm{~g}$ of dried herbage sample was incubated with $20 \mathrm{ml}$ of buffer mixture and $10 \mathrm{ml}$ of filtered rumen fluid. This mixture was incubated in a glass fermenter (Model Fortuna, Wertheim, Germany) at $39 \pm 0.5^{\circ} \mathrm{C}$ in an incubator for $24 \mathrm{~h}$. The initial volumes of the in vitro glass fermenter were recorded. Each sample was studied in triplicate. Also, three blank syringes (without sample, rumen fluid + buffer mixture) were used to calculate the total gas production. After $24 \mathrm{~h}$ of incubation, the total gas volume was recorded from the calibrated scale in the in vitro glass fermenter.

The ME and organic matter digestibility (OMd) values of the herbages were calculated using equations by Menke and Steingass (1988) as follows:

$\mathrm{ME}(\mathrm{MJ} / \mathrm{kg} \mathrm{DM})=2.20+0.136 \times \mathrm{Gas} 24 \mathrm{~h}+$ $0.057 \times \mathrm{CP}$

OMd $(\mathrm{g} / \mathrm{kg} \mathrm{DM})=14.88+0.889 \times \mathrm{Gas} 24 \mathrm{~h}+$ $0.45 \times \mathrm{CP}+0.0651 \times$ ash .

Net energy for lactation $\left(\mathrm{NE}_{\mathrm{L}}\right)$ was calculated using the equation:

$\mathrm{NE}_{\mathrm{L}}(\mathrm{MJ} / \mathrm{kg} \mathrm{DM})=0.115 \times \mathrm{GP}+0.0054 \times \mathrm{CP}+$ $0.014 \times \mathrm{EE}-0.0054 \times$ ash -0.36 ;

where: Gas $24 \mathrm{~h}-24 \mathrm{~h}$ net gas production $(\mathrm{ml} / 200 \mathrm{mg})$, $\mathrm{CP}$-crude protein ( $\mathrm{g} / \mathrm{kg} \mathrm{DM}), \mathrm{CA}$ - crude ash content $(\mathrm{g} / \mathrm{kg} \mathrm{DM})$ and $\mathrm{EE}$ - ether extract (g/kg DM).

\section{Determination of organic acids in the in vitro digestion fluid}

The total gas volume at $24 \mathrm{~h}$ of in vitro incubation was recorded, and $10 \mathrm{ml}$ of digestion fluid in the glass fermenter was collected in Falcon tubes. The fluids were frozen at $-20{ }^{\circ} \mathrm{C}$ until analyses when the tubes were thawed at room temperature. Then, $2 \mathrm{ml}$ of digestion fluid were placed into micro-centrifuge tubes and centrifuged at $15000 \mathrm{rpm}$ for $15 \mathrm{~min}$ in a micro-centrifuge (Gyrozen 1524, Gyrozen Co. Ltd., Daejeon, Korea). After that, $1.25 \mathrm{ml}$ of the supernatant acidified with $0.25 \mathrm{ml}$ of meta-phosphoric acid solution $(25 \%, \mathrm{w} / \mathrm{v})$ for deproteinization, was mixed in a vial for gas chromatography (GC). Analysis of VFAs in the in vitro digestion fluid was determined by using a GC device (Thermo Trace 1300, Thermo Scientific, Waltham, MA, USA) with an auto-sampler (Thermo AI-1310, Thermo Scientific, Waltham, MA, USA). The GC device was equipped with a FID and a polyethylene glycol column (length: $60 \mathrm{~m}$, ID: $0.25 \mathrm{~mm}$, film thickness: $0.25 \mu \mathrm{m}$ ) (TG-WAXMS, Thermo Scientific, Waltham, MA, USA). The operation procedure of the device was according to the study of Ersahince and Kara (2017). A standard organic acid mixture was used to determine retention time and calibration curve $\left(\mathrm{R}^{2}=0.99\right)$. The concentrations (mmol/l) of AA, PA, BA, IBA, VA and IVA were identified using the Xcalibur software program (Thermo Scientific, Waltham, MA, USA) according to retention time and peak area in the chromatograms.

\section{Statistical analysis}

The data were first subjected to Levene's test to detect the variance homogeneity. One-way variance analyses (ANOVA) were implemented for homogeneous variances by General Linear Model procedures to test treatment differences.

The data were analysed by the following statistical model:

$$
\mathrm{Y}_{i}=\mu+\mathrm{S}_{i}+\mathrm{e}_{i}
$$

where: $\mathrm{Y}_{i}$ - investigated parameter (e.g., gas production), $\mu-$ general mean, $\mathrm{S}_{i}-i^{\text {th }}$ effect of phenological stage and $\mathrm{e}_{i}$ - random residual effect.

The means were separated by Tukey's multiple range test at $P<0.05$. Eight samples of yellow sweet clover herbage for each phenological stage and four samples of yellow sweet clover silage for each phenological stage were analysed by the aforementioned statistical model (SPSS 17.0 software, IBM Corp., Armonk, NY, USA).

Linear relations among the CP, NDFom, ADFom, NFC and MDA of yellow sweet clover herbage and the $\mathrm{pH}, \mathrm{DM}, \mathrm{MDA}, \mathrm{BA}, \mathrm{PA}$ and AA of yellow sweet clover silage were determined using Pearson's correlation through SPSS 17.0 software (IBM Corp., Armonk, NY, USA).

\section{Results}

\section{Chemical composition of yellow sweet clover herbages}

The CP and ash contents of yellow sweet clover herbages at vegetative and early flowering stages were higher than those of the full flowering stage $(P<0.05)$. The ash content of yellow sweet clover herbages linearly decreased with plant phenological 
Table 1. Nutrient matter, MDA and fatty acid content of Melilotus officinalis herbages at different phenological stages

\begin{tabular}{|c|c|c|c|c|c|c|c|c|c|c|c|}
\hline \multirow[t]{2}{*}{ Indices } & $\mathrm{CP}$ & NDFom & ADFom & NFC & EE & Ash & \multirow{2}{*}{$\begin{array}{l}\text { MDA, } \\
\mathrm{mg} / \mathrm{kg} \text { DM }\end{array}$} & $\begin{array}{l}\text { Palmitic } \\
\text { acid }\end{array}$ & $\begin{array}{l}\text { Oleic } \\
\text { acid }\end{array}$ & $\begin{array}{l}\text { Linoleic } \\
\text { acid }\end{array}$ & $\begin{array}{l}\text { Alpha-linolenic } \\
\text { acid }\end{array}$ \\
\hline & \multicolumn{6}{|c|}{$\%$ in DM } & & \multicolumn{4}{|c|}{$\%$ in total fatty acids of DM } \\
\hline \multicolumn{12}{|l|}{ Phenological stages } \\
\hline vegetative stage & $19.15^{\mathrm{a}}$ & $38.98^{b}$ & $27.18^{b}$ & $29.49^{a}$ & 2.66 & $9.69^{\mathrm{a}}$ & 434.07 & $17.07^{b}$ & $5.79^{b}$ & $16.04^{\mathrm{a}}$ & $43.57^{\mathrm{a}}$ \\
\hline early flowering stage & $21.44^{a}$ & $40.87^{\mathrm{b}}$ & $28.51^{\mathrm{b}}$ & $25.40^{\mathrm{b}}$ & 2.67 & $9.60^{\mathrm{a}}$ & 379.49 & $16.91^{\mathrm{b}}$ & $4.48^{b}$ & $16.33^{a}$ & $45.07^{a}$ \\
\hline full flowering stage & $16.95^{b}$ & $44.64^{a}$ & $31.11^{a}$ & $26.63^{b}$ & 3.07 & $8.68^{b}$ & 481.26 & $17.95^{\mathrm{a}}$ & $6.73^{\mathrm{a}}$ & $14.57^{\mathrm{b}}$ & $40.69^{b}$ \\
\hline SD & 2.15 & 2.70 & 2.72 & 1.95 & 0.32 & 0.50 & 84.71 & 0.64 & 1.37 & 0.86 & 2.39 \\
\hline SEM & 0.87 & 1.10 & 1.11 & 0.79 & 0.13 & 0.20 & 34.58 & 0.21 & 0.45 & 0.28 & 0.79 \\
\hline \multicolumn{12}{|l|}{$P$-value } \\
\hline L & 0.114 & 0.013 & 0.037 & 0.029 & 0.284 & 0.003 & 0.262 & 0.720 & 0.929 & 0.002 & 0.077 \\
\hline$Q$ & 0.029 & 0.379 & 0.802 & 0.024 & 0.526 & 0.022 & 0.958 & 0.007 & 0.010 & 0.005 & 0.045 \\
\hline
\end{tabular}

$\mathrm{CP}$ - crude protein, NDFom - neutral detergent fibre without ash, ADFom - acid detergent fibre without ash, NFC - non-fibre carbohydrate, $\mathrm{EE}$ - diethyl ether extract, DM - dry matter, MDA - malondialdehyde, SD - standard deviation, SEM - standard error of means, L - linear term, $Q$ - quadratic term; ${ }^{\text {ab }}$ - average values with different superscripts in the same column are significantly different at $P<0.05$

stages $(P<0.05)$. The NDFom and ADFom contents of yellow sweet clover herbages linearly increased with plant phenological stages $(P<0.05)$. For all phenological stages of yellow sweet clover herbages, the highest NFC content was in the vegetative stage. The NFC content linearly decreased with increasing phenological stages $(P<0.05)$. The EE and MDA contents of yellow sweet clover herbages were similar for all phenological stages $(P>0.05)$ (Table 1$)$.

The fatty acids at the highest ratio in total fatty acids were palmitic, oleic, linoleic and alphalinolenic ones. The palmitic and oleic acid contents
$(P<0.05)$ (Table 1$)$. The MUFA and $\mathrm{n}-9$ content in vegative stage herbage did not differ from full flowering state but was higher that in early stage $(P<0.05)$. The PUFA content was the highest in early stage $(P<0.05)$. The $\mathrm{n}-3$ content in early stage herbage did not differ from full flowering state but was higher that in vegetative stage $(P<0.05)$. MCFA was the lowest in vegetative stage and the highest in full flowering stage $(P<0.05)$. LCFA was the lowest in full flowering stage. There was no difference in n-6 and VLCFA $(P>0.05)$ (Table 2).

Table 2. The fatty acid content of Melilotus officinalis herbages at different phenological stages, as $\%$ in total fatty acids of dry matter

\begin{tabular}{|c|c|c|c|c|c|c|c|c|}
\hline Indices & MUFA & PUFA & $n-3$ & $n-6$ & $n-9$ & MCFA & LCFA & VLCFA \\
\hline \multicolumn{9}{|l|}{ Phenological stage } \\
\hline vegetation stage & $9.60^{\mathrm{a}}$ & $65.06^{b}$ & $44.72^{b}$ & 20.33 & $6.91^{\mathrm{a}}$ & $0.51^{c}$ & $98.47^{a}$ & 0.99 \\
\hline early flowering stage & $7.13^{b}$ & $69.66^{a}$ & $48.24^{a}$ & 21.42 & $4.68^{b}$ & $0.71^{\mathrm{b}}$ & $98.13^{a}$ & 1.14 \\
\hline full flowering stage & $8.77^{\mathrm{ab}}$ & $65.03^{b}$ & $46.06^{\mathrm{ab}}$ & 18.97 & $6.78^{\mathrm{ab}}$ & $1.52^{\mathrm{a}}$ & $97.34^{b}$ & 1.11 \\
\hline SD & 1.28 & 2.39 & 2.06 & 1.62 & 1.32 & 0.46 & 0.51 & 0.12 \\
\hline SEM & 0.42 & 0.79 & 0.68 & 0.54 & 0.44 & 0.15 & 0.17 & 0.04 \\
\hline \multicolumn{9}{|l|}{$P$-value } \\
\hline L & 0.243 & 0.967 & 0.342 & 0.284 & 0.864 & 0.001 & 0.001 & 0.259 \\
\hline Q & 0.010 & 0.001 & 0.044 & 0.129 & 0.012 & 0.001 & 0.083 & 0.306 \\
\hline
\end{tabular}

MUFA - monounsaturated fatty acids, PUFA - polyunsaturated fatty acids, MCFA - medium-chain fatty acids, LCFA - long-chain fatty acids, VLCFA - very long-chain fatty acids, SD - standard deviation, SEM - standard error of means, L - linear term, $Q$ - quadratic term; abc - average values with different superscripts in the same column are significantly different at $P<0.05$

of yellow sweet clover herbage at full flowering stage were the highest than those of other phenological stages $(P<0.05)$. The palmitic and oleic acid contents of herbage linearly increased with the plant growing stage $(P<0.05)$. The linoleic and alpha-linolenic acid contents of yellow sweet clover herbages at vegetative and early flowering stages were higher than those of the full flowering stage $(P<0.05)$. The linoleic and alpha-linolenic acid contents of herbage decreased with the plant growing stage

\section{In vitro digestion values of yellow sweet clover herbages}

The in vitro total gas production, $\mathrm{ME}, \mathrm{NE}_{\mathrm{L}}$ and OMd values for all phenological stages of yellow sweet clover herbages were similar $(P>0.05)$ (Table 3). The molarities and percentages of AA, PA, BA, IVA, VA, IBA, other volatile acids and TVFA in the in vitro fermentation fluid of yellow sweet clover herbages at different phenological stages were similar $(P>0.05)$ (Table 4$)$. 
Table 3. The in vitro total gas production and estimated ruminal fermentation values of Melilotus officinalis herbages at different phenological stages

\begin{tabular}{lllll}
\hline Indices & $\begin{array}{l}\text { Total gas } \\
\text { production, } \\
\text { ml/0.2 g DM }\end{array}$ & $\begin{array}{l}\mathrm{ME}, \\
\mathrm{MJ} / \mathrm{kg} \text { DM }\end{array}$ & $\begin{array}{l}\mathrm{NE}_{\mathrm{L}}, \\
\mathrm{MJ} / \mathrm{kg} \mathrm{DM}\end{array}$ & $\begin{array}{l}\mathrm{OMd}, \\
\% \mathrm{DM}\end{array}$ \\
\hline $\begin{array}{l}\text { Phenological stage } \\
\quad \text { vegetation stage }\end{array}$ & 43.14 & 9.16 & 5.61 & 62.48 \\
$\quad$ early flowering stage & 43.17 & 9.29 & 5.75 & 63.54 \\
$\quad$ full flowering stage & 42.95 & 9.01 & 5.49 & 61.09 \\
SD & 2.70 & 0.38 & 1.32 & 2.62 \\
SEM & 0.78 & 0.11 & 0.09 & 0.75 \\
$P$-value & & & & \\
$\quad \mathrm{L}$ & 0.930 & 0.615 & 0.612 & 0.479 \\
$\mathrm{Q}$ & 0.943 & 0.416 & 0.374 & 0.309 \\
\hline
\end{tabular}

$\mathrm{DM}$ - dry matter, $\mathrm{ME}$ - metabolizable energy, $\mathrm{NE}_{\mathrm{L}}$ - net energy for lactation, OMd - organic matter digestibility, SD - standard deviation, SEM - standard error of means, $L$ - linear term, $Q$ - quadratic term, flowering stage $(P<0.05)$. The $\mathrm{CP}$ and ash content of silage linearly decreased with the plant phenological stages $(P<0.05)$. The MDA, oleic acid, linoleic acid, MUFA, n-3, n-6, n-9 and VLCFA contents of yellow sweet clover silages did not differ between phenological stages $(P>0.05)$ (Table 5).

The alpha-linolenic acid percentage in total fatty acids of yellow sweet clover silages at the vegetative stage were higher than that of the full flowering stage but similar to that of the early flowering stage $(P<0.05)$ (Table 5). The PUFA and LCFA percentages in total fatty acids of silages in vegetative and early flowering stages were the same, but higher than those of full flowering stage $(P<0.05)$ (Table 6). The MCFA percentage in total fatty acids of yellow sweet clover silages at the full flowering stage was higher than those of other phenological stages $(P<0.05)$ (Table 6).

Table 4. The organic acids in the in vitro digestion of Melilotus officinalis herbages at different phenological stages

\begin{tabular}{|c|c|c|c|c|c|c|c|}
\hline \multirow{2}{*}{ Indices } & \multicolumn{3}{|c|}{ Phenological stage } & \multirow{2}{*}{ SD } & \multirow{2}{*}{ SEM } & \multicolumn{2}{|c|}{$P$-value } \\
\hline & vegetative stage & early flowering stage & full flowering stage & & & $L$ & Q \\
\hline \multicolumn{8}{|c|}{ Organic acids as $\mathrm{mM} / \mathrm{l}$ for in vitro fermentation fluid } \\
\hline acetic acid (AA) & 75.03 & 79.14 & 76.92 & 3.82 & 1.27 & 0.575 & 0.295 \\
\hline propionic acid (PA) & 18.79 & 20.12 & 19.11 & 1.05 & 0.35 & 0.708 & 0.149 \\
\hline butyric acid (BA) & 13.56 & 14.40 & 13.82 & 0.70 & 0.24 & 0.659 & 0.202 \\
\hline iso-valeric acid (IVA) & 2.52 & 2.70 & 2.68 & 0.12 & 0.04 & 0.142 & 0.266 \\
\hline valeric acid (VA) & 1.90 & 2.07 & 1.97 & 0.10 & 0.03 & 0.285 & 0.060 \\
\hline iso-butyric acid (IBA) & 1.35 & 1.42 & 1.42 & 0.06 & 0.02 & 0.263 & 0.461 \\
\hline other volatile acids (OVA) & 0.76 & 0.80 & 0.77 & 0.02 & 0.01 & 0.629 & 0.116 \\
\hline TVFA & 113.93 & 120.67 & 116.71 & 5.85 & 1.95 & 0.582 & 0.244 \\
\hline \multicolumn{8}{|c|}{ Organic acids as $\%$ in TVFA of in vitro fermentation fluid } \\
\hline acetic acid & 65.84 & 65.58 & 65.90 & 0.15 & 0.05 & 0.323 & 0.071 \\
\hline propionic acid & 16.49 & 16.67 & 16.37 & 0.15 & 0.05 & 0.165 & 0.112 \\
\hline butyric acid & 11.90 & 11.94 & 11.85 & 0.05 & 0.02 & 0.144 & 0.086 \\
\hline iso-valeric acid & 2.22 & 2.24 & 2.30 & 0.05 & 0.02 & 0.070 & 0.628 \\
\hline valeric acid & 1.67 & 1.72 & 1.70 & 0.03 & 0.01 & 0.121 & 0.129 \\
\hline iso-butyric acid & 1.19 & 1.18 & 1.22 & 0.02 & 0.01 & 0.175 & 0.165 \\
\hline other volatile acids & 0.66 & 0.66 & 0.66 & 0.01 & 0.01 & 0.513 & 0.960 \\
\hline
\end{tabular}

SD - standard deviation, SEM - standard error of means, $L$ - linear term, $Q$ - quadratic term; TVFA (total volatile fatty acids; mmol/l) = $\mathrm{AA}(\mathrm{mmol} / \mathrm{l})+\mathrm{PA}(\mathrm{mmol} / \mathrm{l})+\mathrm{BA}(\mathrm{mmol} / \mathrm{l})+\mathrm{IBA}(\mathrm{mmol} / \mathrm{l})+\mathrm{VA}(\mathrm{mmol} / \mathrm{l})+\mathrm{IVA}(\mathrm{mmol} / \mathrm{l})+\mathrm{OVA}(\mathrm{mmol} / \mathrm{l}) ;$ other volatile acids = n-heptanoic acid + hexanoic acid

\section{Chemical composition of yellow sweet clover silages}

The DM, NDFom and ADFom contents, and palmitic acid percentage in total fatty acids of yellow sweet clover silages at the full flowering stage were higher than those of other stages $(P<0.05)$. The DM, NDFom, ADFom and palmitic acid of silage linearly increased with the plant phenological stages $(P<0.05)$. The $\mathrm{CP}$ and ash contents of yellow sweet clover silages at vegetative and early flowering stages were higher than those of the full

\section{The acidity values and ammonia contents of yellow sweet clover silages}

Melilotus officinalis silages $\mathrm{pH}$ values were 3.93 for the vegetative stage, 3.88 for the early flowering stage and 4.25 for the full flowering stage $(P<0.05)$. The $\mathrm{pH}$ value in silage fluid and PA in the silage DM of the full flowering stage was higher than those of other stages $(P<0.05)$. The LA contents in the DM of yellow sweet clover silages at vegetative and early flowering stages were higher than that of the full flowering stage $(P<0.05)$. The silage acidity 
Table 5. Nutrient matter, MDA and fatty acids of Melilotus officinalis silages at different phenological stages

\begin{tabular}{|c|c|c|c|c|c|c|c|c|c|c|c|c|}
\hline \multirow[t]{2}{*}{ Indices } & DM & $\mathrm{CP}$ & NDFom & ADFom & NFC & $\mathrm{EE}$ & Ash & \multirow{2}{*}{$\begin{array}{l}\text { MDA, } \\
\mathrm{mg} / \mathrm{kg} \text { DM }\end{array}$} & $\begin{array}{l}\text { Palmitic } \\
\text { acid }\end{array}$ & $\begin{array}{l}\text { Oleic } \\
\text { acid }\end{array}$ & $\begin{array}{l}\text { Linoleic } \\
\text { acid }\end{array}$ & $\begin{array}{l}\text { Alpha-linolenic } \\
\text { acid }\end{array}$ \\
\hline & \multicolumn{7}{|c|}{$\%$ in DM } & & \multicolumn{4}{|c|}{$\%$ in total fatty acids of silage DM } \\
\hline \multicolumn{13}{|l|}{ Phenological stage } \\
\hline vegetative stage & $23.65^{b}$ & $21.24^{a}$ & $35.01^{c}$ & $23.26^{c}$ & 30.55 & 3.53 & $9.67^{\mathrm{a}}$ & 1518.13 & $17.35^{b}$ & 4.58 & 18.85 & $47.46^{\mathrm{a}}$ \\
\hline early flowering stage & $23.00^{\mathrm{b}}$ & $22.78^{a}$ & $37.60^{\mathrm{b}}$ & $25.95^{\mathrm{b}}$ & 27.02 & 2.80 & $9.79^{a}$ & 1164.92 & $17.41^{\mathrm{b}}$ & 5.14 & 19.25 & $46.37^{\mathrm{ab}}$ \\
\hline full flowering stage & $25.00^{\mathrm{a}}$ & $16.48^{b}$ & $42.16^{\mathrm{a}}$ & $29.36^{\mathrm{a}}$ & 29.69 & 2.90 & $8.75^{b}$ & 1672.45 & $20.24^{a}$ & 6.46 & 16.60 & $39.76^{b}$ \\
\hline SD & 0.88 & 2.96 & 3.25 & 2.77 & 1.81 & 0.57 & 0.51 & 267.59 & 1.51 & 1.36 & 1.51 & 3.98 \\
\hline SEM & 0.29 & 1.21 & 1.32 & 1.13 & 0.74 & 0.23 & 0.20 & 109.24 & 0.61 & 0.55 & 0.61 & 1.62 \\
\hline \multicolumn{13}{|l|}{$P$-value } \\
\hline L & 0.010 & 0.003 & $<0.001$ & 0.002 & 0.453 & 0.368 & 0.001 & 0.432 & 0.007 & 0.261 & 0.119 & 0.024 \\
\hline$Q$ & 0.014 & 0.003 & 0.045 & 0.526 & 0.037 & 0.467 & 0.003 & 0.062 & 0.036 & 0.765 & 0.188 & 0.179 \\
\hline
\end{tabular}

DM - dry matter, CP - crude protein, NDFom - neutral detergent fibre without ash, ADFom - acid detergent fibre without ash, NFC - non-fibre carbohydrate, EE - diethyl ether extract, MDA - malondialdehyde, SD - standard deviation, SEM - standard error of means, L - linear term, $\mathrm{Q}$ - quadratic term; abc - average values with different superscripts in the same column are significantly different at $P<0.05$

Table 6. Fatty acids of Melilotus officinalis silages at different phenological stages, as \% in total fatty acids of dry matter

\begin{tabular}{lcccccccc}
\hline Indices & MUFA & PUFA & $\mathrm{n}-3$ & $\mathrm{n}-6$ & $\mathrm{n}-9$ & MCFA & LCFA & VLCFA \\
\hline Phenological stage & & & & & & & & \\
$\quad$ vegetative stage & 6.65 & $70.01^{\mathrm{a}}$ & 50.46 & 19.54 & 4.68 & $0.62^{\mathrm{b}}$ & $98.70^{\mathrm{a}}$ & 0.68 \\
$\quad$ early flowering stage & 6.87 & $69.94^{\mathrm{a}}$ & 50.24 & 19.70 & 5.24 & $0.67^{\mathrm{b}}$ & $98.63^{\mathrm{a}}$ & 0.68 \\
$\quad$ full flowering stage & 8.09 & $62.39^{\mathrm{b}}$ & 45.50 & 16.88 & 6.57 & $1.56^{\mathrm{a}}$ & $97.53^{\mathrm{b}}$ & 0.91 \\
SD & 1.18 & 4.43 & 3.08 & 1.68 & 1.37 & 0.47 & 0.58 & 0.13 \\
SEM & 0.48 & 1.80 & 1.25 & 0.68 & 0.56 & 0.19 & 0.23 & 0.05 \\
P-value & & & & & & & & \\
$\quad$ L & 0.330 & 0.045 & 0.121 & 0.107 & 0.263 & $<0.001$ & $<0.001$ & 0.059 \\
Q & 0.676 & 0.204 & 0.342 & 0.237 & 0.770 & 0.002 & $<0.001$ & 0.159 \\
\hline
\end{tabular}

MUFA - monounsaturated fatty acids, PUFA - polyunsaturated fatty acids, MCFA - medium-chain fatty acids, LCFA - long-chain fatty acids, VLCFA - very long-chain fatty acids, SD - standard deviation, SEM - standard error of means, L - linear term, Q - quadratic term; ab - average values with different superscripts in the same column are significantly different at $P<0.05$

Table 7. Acidity values of Melilotus officinalis silages at different phenological stages

\begin{tabular}{|c|c|c|c|c|c|c|c|}
\hline \multirow{2}{*}{ Indices } & \multirow{2}{*}{$\mathrm{pH}$} & Lactic acid & Acetic acid & Propionic acid & Butyric acid & Hexanoic acid & \multirow{2}{*}{$\begin{array}{l}\text { Ammonia, } \\
\text { g/l silage fluid }\end{array}$} \\
\hline & & \multicolumn{5}{|c|}{$\%$ in DM of silage } & \\
\hline \multicolumn{8}{|l|}{ Phenological stage } \\
\hline vegetative stage & $3.93^{b}$ & $6.30^{\mathrm{a}}$ & 0.658 & $0.010^{b}$ & 0.002 & 0.012 & 0.27 \\
\hline early flowering stage & $3.88^{b}$ & $5.76^{\mathrm{a}}$ & 0.712 & $0.009^{b}$ & 0.003 & 0.011 & 0.33 \\
\hline full flowering stage & $4.25^{\mathrm{a}}$ & $3.68^{b}$ & 0.727 & $0.013^{a}$ & 0.002 & 0.007 & 0.26 \\
\hline SD & 0.18 & 0.740 & 0.114 & 0.002 & 0.004 & 0.004 & 0.089 \\
\hline SEM & 0.06 & 0.112 & 0.038 & 0.001 & 0.001 & 0.001 & 0.029 \\
\hline \multicolumn{8}{|l|}{$P$-value } \\
\hline L & 0.001 & 0.038 & 0.527 & 0.005 & 0.805 & 0.174 & 0.981 \\
\hline$Q$ & 0.005 & 0.165 & 0.836 & 0.006 & 0.226 & 0.574 & 0.458 \\
\hline
\end{tabular}

DM - dry matter, SD - standard deviation, SEM - standard error of means, L - linear term, Q - quadratic term; ab - average values with different superscripts in the same column are significantly different at $P<0.05$

and LA concentration linearly decreased with the plant phenological stage $(P<0.05)$. The AA, BA and HA contents in the DM of yellow sweet clover silages were similar for all phenological stages $(P>0.05)$. The ammonia content $(\mathrm{g} / \mathrm{l})$ in silage fluid did not differ between examined phenological stages of yellow sweet clover $(P>0.05)$ (Table 7).

\section{Pearson correlations among chemical compositions in Melilotus officinalis silages and herbages}

Yellow sweet clover herbage's EE content was positively correlated with herbage's ADF content $(P<0.05)$. The CP content of yellow sweet clover herbage was negatively correlated with NDFom, 
Table 8. Pearson correlations among chemical compositions in silages and herbage of Melilotus officinalis

\begin{tabular}{|c|c|c|c|c|c|c|c|c|c|c|c|c|}
\hline \multirow{2}{*}{ Indices } & & \multicolumn{5}{|c|}{ Herbage contents } & \multicolumn{6}{|c|}{ Silage values } \\
\hline & & $\overline{\mathrm{CP}}$ & NDFom & ADFom & NFC & MDA & $\overline{\mathrm{pH}}$ & DM & MDA & $\mathrm{BA}$ & PA & $\mathrm{AA}$ \\
\hline \multirow{6}{*}{$\begin{array}{l}\text { Herbage } \\
\text { contents }\end{array}$} & $\mathrm{EE}$ & -0.477 & 0.502 & $0.840^{* *}$ & -0.207 & 0.009 & 0.608 & 0.513 & -0.137 & -0.153 & 0.471 & -0.268 \\
\hline & $\mathrm{CP}$ & 1 & $-0.731^{*}$ & $-0.613^{*}$ & -0.316 & $-0.541^{*}$ & $-0.809^{* *}$ & * $-0.937^{* *}$ & * $-0.785^{*}$ & $0.685^{*}$ & $-0.828^{\star *}$ & 0.162 \\
\hline & NDFom & & 1 & $0.637^{*}$ & -0.397 & 0.434 & $0.808^{* *}$ & * $0.804^{* *}$ & * 0.584 & -0.200 & $0.770^{*}$ & 0.227 \\
\hline & ADFom & & & 1 & -0.110 & 0.054 & $0.693^{*}$ & 0.621 & 0.152 & -0.323 & 0.590 & -0.322 \\
\hline & NFC & & & & 1 & 0.134 & -0.037 & 0.148 & 0.365 & -0.643 & 0.044 & -0.464 \\
\hline & MDA & & & & & 1 & 0.499 & 0.523 & $0.837^{*}$ & -0.625 & 0.730 & 0.265 \\
\hline \multirow{5}{*}{$\begin{array}{l}\text { Silage } \\
\text { values }\end{array}$} & $\mathrm{pH}$ & & & & & & 1 & $0.925^{\star *}$ & * 0.674 & -0.375 & $0.854^{* *}$ & 0.132 \\
\hline & DM & & & & & & & 1 & 0.795 & -0.577 & $0.920^{* *}$ & 0.110 \\
\hline & MDA & & & & & & & & 1 & -0.787 & $0.825^{\star}$ & 0.231 \\
\hline & $\mathrm{BA}$ & & & & & & & & & 1 & -0.564 & 0.111 \\
\hline & PA & & & & & & & & & & 1 & 0.253 \\
\hline
\end{tabular}

EE - diethyl ether extract, CP - crude protein, NDFom - neutral detergent fibre without ash, ADFom - acid detergent fibre without ash, NFC - non-fibre carbohydrate, MDA - malondialdehyde, DM - dry matter, BA - butyric acid, PA - propionic acid, AA - acetic acid; ${ }^{*}-P<0.05,{ }^{* *}-P<0.01$

Table 9. Pearson correlations among fatty acids and other chemical contents in herbage and silage for Melilotus officinalis

\begin{tabular}{|c|c|c|c|c|c|c|c|}
\hline \multirow{2}{*}{ Indices } & \multicolumn{2}{|l|}{ Silage } & \multirow{2}{*}{$\begin{array}{l}\text { Herbage } \\
\text { MDA }\end{array}$} & \multicolumn{4}{|l|}{ Silage } \\
\hline & $\mathrm{DM}$ & MDA & & $\mathrm{LA}$ & BA & PA & $\mathrm{AA}$ \\
\hline \multicolumn{8}{|l|}{ Silage } \\
\hline palmitic acid (C16:0) & $0.926^{* *}$ & 0.716 & 0.611 & -0.449 & -0.461 & $0.947^{* *}$ & 0.239 \\
\hline oleic acid (C18:1) & $0.697^{*}$ & 0.506 & 0.482 & -0.429 & -0.517 & $0.844^{* *}$ & 0.198 \\
\hline linoleic acid (C18:2) & $-0.852^{* *}$ & $-0.816^{*}$ & $-0.855^{\star}$ & 0.295 & 0.542 & $-0.924^{* *}$ & -0.253 \\
\hline alpha-linoleic acid (C18:3) & $-0.885^{\star *}$ & $-0.654^{*}$ & $-0.549^{*}$ & 0.483 & 0.444 & $-0.941^{* *}$ & -0.280 \\
\hline \multicolumn{8}{|l|}{ Herbage } \\
\hline palmitic acid (C16:0) & 0.586 & 0.451 & 0.006 & -0.475 & -0.569 & 0.345 & -0.469 \\
\hline oleic acid (C18:1) & 0.612 & $0.875^{*}$ & 0.594 & -0.531 & -0.582 & 0.620 & 0.440 \\
\hline linoleic acid (C18:2) & $-0.929^{* *}$ & $-0.777^{*}$ & $-0.796^{*}$ & 0.543 & 0.432 & $-0.935^{\star *}$ & -0.450 \\
\hline alpha-linoleic acid (C18:3) & $-0.803^{* *}$ & $-0.842^{*}$ & $-0.738^{*}$ & 0.430 & 0.448 & $-0.842^{* *}$ & -0.568 \\
\hline
\end{tabular}

DM - dry matter, MDA - malondialdehyde, LA - lactic acid, BA - butyric acid, PA - propionic acid, AA - acetic acid; * correlation is significant at the 0.05 level (2-tailed), ${ }^{* *}$ - correlation is significant at the 0.01 level (2-tailed)

ADFom and MDA contents of herbage and $\mathrm{pH}$ value, DM, MDA and PA contents of silage; and positively correlated with the BA contents of silage $(P<0.05)$. The NDFom content of herbage was positively correlated with herbage ADF content, silage $\mathrm{pH}$ value, silage DM and silage PA content $(P<0.05)$. The ADFom content of herbage was positively correlated with silage $\mathrm{pH}(P<0.05)$.

The MDA content of herbage was positively correlated with silage MDA content $(P<0.05)$.

The PA content of silage was correlated with $\mathrm{pH}$ value, DM and MDA contents of silage $(P<0.05)$ (Table 8).

The silage palmitic acid content was positively correlated with silage DM and silage PA content $(P<0.05)$. Silage oleic acid content was positively correlated with silage DM and silage PA content $(P<0.05)$. The linoleic acid content of herbage and silage were negatively correlated with silage DM, silage MDA, herbage MDA and silage PA contents
$(P<0.05)$. The alpha-linoleic acid contents of herbage and silage were negatively correlated with silage DM, silage MDA, herbage MDA and silage PA contents $(P<0.05)$.

\section{Discussion}

Yellow sweet clover (Melilotus officinalis L.), which is a common legume species, has the potential to be used as a forage crop for herbivores. The species is native to Eurasia and naturalized in North America, Africa and Australia (Cornara et al., 2016). The yellow sweet clover did not culture like other legume forages, such as Medicago sativa, Onobrychis sativa, Trifolium pratense and Trifolium repens (Dumlu and Tan, 2009; Luo et al., 2014). There are few studies about the nutritional content and digestibility capacity of yellow sweet clover. In the present study, yellow sweet clover herbages' $\mathrm{CP}$ contents at different phenological stages ranged 
from about 17 to about 21\% in DM. Yisehak (2008) stated that yellow sweet clover herbage's CP content at the middle of the flowering stage was $22 \%$ of DM. Canbolat and Karaman (2009) found that the CP of yellow sweet clover herbage at the flowering stage included at a similar level with our study results. The CP content $(24.7 \%)$ of yellow sweet clover herbage at the flowering stage in the study of Çaçan et al. (2015) was higher than the results of the present study. The CP and ash contents of yellow sweet clover herbages at vegetative and early flowering stages were higher than those of the full flowering stage. The NDFom and ADFom contents of yellow sweet clover herbages at the full flowering stage were higher than those of vegetative and early flowering stages; such results were similar to the results of previous researchers (Ersahince and Kara, 2017; Kara et al., 2018). Yisehak (2008) stated that the NDF and ADF contents of yellow sweet clover herbage at $50 \%$ flowering stage were 37 and $33 \%$ in DM, respectively. For all phenological stages of yellow sweet clover herbages, the highest non-structural carbohydrates (NSC) content was in the vegetative stage, similar to the results of other forage plants by previous researchers (Kara et al., 2018). Previous researchers determined that the yellow sweet clover herbage at the flowering stage included about $7 \%$ ash, $38-43 \%$ NDF and 22-33\% ADF in DM (Canbolat and Karaman 2009; Çaçan et al., 2015). In another study, Ateş and Seren (2020) demonstrated that the CP content of Melilotus caeruleus herbage was decreased by the growth stage, and ADF and NDF contents were increased by the growth stage. The $\mathrm{CP}$ content of yellow sweet clover was correlated with ADFom and NDFom contens. The nutritional difference between the present and previous studies on yellow sweet clover herbage can be related to soil type, salinity, water restriction, and temperature and climate variables.

The DM contents of yellow sweet clover silage at different growing stages in the present study were ranged from 23 to $25 \%$. The highest silage DM content was in the full flowering stage. According to the results, silage DM increases as the plant growth period progresses. In line with the study results, the researchers determined that the DM value of yellow sweet clover silage harvested at the end of the flowering stage was $30.6 \%$ (Dumlu and Tan, 2009). In the present study, the $\mathrm{CP}$ value of yellow sweet clover silage varied from approximately 23 to $16.5 \%$ in DM. The CP of yellow sweet clover silage for all phenological stages in the present study was higher than the CP content (about 12\% in DM) in the silage of yellow sweet clover at the end of the flowering stage of Dumlu and Tan (2009).

The total gas production volume of in vitro fermentation depends on the composition of nutrient content, the ratio of structural and NSC, the presence of inhibitor for gas production, the diet of the donor animal, and the quality of fermentation provided by the microflora in the rumen fluid (Szumacher-Strabel and Cieślak, 2012; Kara et al., 2015). The in vitro gas production and in vitro estimated digestion values of forage decrease with the increase in NDF and ADF value; and increase with the increase in NFC (Ersahince and Kara, 2017; Kara et al., 2018). In the present study, although NDFom and ADFom values increased linearly as the plant phenological period progressed, this effect was not observed on in vitro digestion values. Although the NFC value of yellow sweet clover herbage ranged from about 25 to $29 \%$, there was no significant difference in the in vitro gas production and estimated digestion values. This result was interesting. Similar in vitro digestion levels in different phenological stages of the plant may also be due to the level of hemicellulose, which is an easily digested fibre source. Because it was seen that the hemicellulose levels (NDFomADFom) according to the plant growth stage of yellow sweet clover herbage were approximately 12,12 and $13 \%$, respectively. In general, the in vitro gas production and in vitro estimated digestion values for the silage and herbage samples of yellow sweet clover in the presented study were similar to the values of the lucerne herbage and maize silage (Canbolat and Karaman, 2009; Kara, 2015; Kara et al., 2016). This showed that the in vitro total gas production, $\mathrm{OMd}$ and $\mathrm{ME}$ values of herbage of yellow sweet clover at the flowering stage were $51.2 \mathrm{ml} / 0.2 \mathrm{~g}, 72 \%$ and $10 \mathrm{MJ} / \mathrm{kg} \mathrm{DM}$ at $24 \mathrm{~h}$ of incubation. Yisehak (2008) showed that yellow sweet clover herbage's ME value at 50\% flowering stage was $9.2 \mathrm{MJ} / \mathrm{kg} \mathrm{DM}$. In vitro rumen fermentation, TVFA molarities $(114-120 \mathrm{mM} / \mathrm{l})$ in digestive fluids for yellow sweet clover herbages at different phenological stages were at reference values (Ersahince and Kara, 2017; Kara et al., 2018). The molarities of VFAs in rumen fluid change by plant cell wall carbohydrates, easily digestible carbohydrates, and other nutrient compositions in substrates (Kara, 2015). The AA molarity in rumen fluid was also in values that could be achieved by fermentation of a plant cell wall carbohydrates-weighted substrate.

Yellow sweet clover silage's $\mathrm{pH}$ values for vegetative and early flowering stages were at ideal 
fermentation acidity range $(\mathrm{pH} 3.88$ and 3.93 , respectively). The LA contents of yellow sweet clover silages for vegetative and early flowering stages were higher than that of the full flowering stage. However, yellow sweet clover silage's $\mathrm{pH}$ value for full flowering stages was high for ideal fermentation acidity ( $\mathrm{pH} 4.25)$. The $\mathrm{pH}$ value of yellow sweet clover silage for all phenological stages in the present study was lower than the $\mathrm{pH}$ content (pH 4.6) in the silage of yellow sweet clover at the end of the flowering stage of Dumlu and Tan (2009). For yellow sweet clover silage, it is understood that silage acidity decreases ( $\mathrm{pH}$ value increases) as the plant growing period progresses. Yellow sweet clover silage's $\mathrm{pH}$ value was positively correlated with silage DM content and silage PA content. The PA acidity value ( $\mathrm{pKa} 4.88$ ) was lower than the acidity values of LA (pKa 3.86) and AA (pKa 4.75). Yellow sweet clover silage's $\mathrm{pH}$ value being positively correlated with silage PA content did not reduce silage acidity. The reason for this may be the acidity value (pKa 4.88) of PA. In the present study, the NDFom contents of yellow sweet clover silage ranged from 35 to $42 \%$ in DM. The NDFom contents of yellow sweet clover silage were lower than that of yellow sweet clover silage at the end of the flowering stage of Dumlu and Tan (2009).

Forages include the changing of fatty acids at different ratios according to plant species, plant part, plant phenological stage, etc. In the present study, the palmitic acid (C16:0) has among all SFA the highest concentration in yellow sweet clover herbages and silages at different phenological stages. In a previous study, it was demonstrated that palmitic acid concentrations (in total fatty acids) of common forages used in dairy cattle diet were $15-30 \%$ for alfalfa (herbage, silage or hay), $16-20 \%$ for perennial ryegrass (herbage), $14-20 \%$ for red clover (fresh, silage or hay), 16\% for white clover (herbage, silage) and 16\% for maize silage (Vanhatalo et al., 2007; Van Ranst et al., 2009; Dierking et al., 2010; Glasser et al., 2013). The approximately $17-20 \%$ palmitic acid concentrations in total fatty acids of yellow sweet clover (herbage and silage) for different phenological stages were similar to other legume forage such as red clover (14-20\% for fresh, silage or hay), white clover (16\% for herbage and silage) and alfalfa (15-30\% for herbage, silage or hay) (Vanhatalo et al., 2007; Van Ranst et al., 2009; Dierking et al., 2010; Glasser et al., 2013). In the present study, palmitic acid in yellow sweet clover herbages and silages increased with a plant growing similarly to that in
Mir et al. (2006) study. The palmitic acid contents of yellow sweet clover herbages and silages in the full flowering stage were very close (about 18 and $20 \%$ in total fatty acids, respectively) which demonstrates that fermentation does not remarkably affect this fatty acid. The oleic acid percentages, which were the highest MUFA in forages in the present study, were about $4-6 \%$ in total fatty acids of yellow sweet clover silages and herbages. The oleic acid and MUFA concentrations in total fatty acid of herbage increasing up to full flowering stage may be related to plant height, leaf:stem ratio, flower ratio and other environmental conditions. The highest percentage of unsaturated fatty acid among total fatty acids in yellow sweet clover had alpha-linolenic acid. The alpha-linolenic acid (C18:3n-3) percentage in total fatty acids of yellow sweet clover silage (about 40-48\%) and herbage (about 41-45\%) lowered with increasing plant growth stage. The alpha-linolenic acid percentage in total fatty acids of herbage ( $42 \%)$, silage $(32 \%)$ and hay $(22 \%)$ of alfalfa, and the herbage $(58 \%)$ and silage $(59 \%)$ of white clover (Glasser et al., 2013) were very variable.

Lipid oxidation of plants depends on the activity of lipoxygenases. Lipoxygenase activity is found in a plant at all phenological stages, and this activity increases when a plant enters the mature and senescence stages or after tissue injury (Han and Zhou, 2013). Lipid peroxidation refers to a series of free radical's reactions conducted in unsaturated fatty acids and has been widely used to indicate cell oxidative damage (DaCosta and Huang, 2007; Talbi et al., 2015). The MDA reflects lipid peroxidation in plant cells and external stress responses (Prasad, 1996; Thompson et al., 1998). Han and Zhou (2013) proved that SFA (C16:0 and $\mathrm{C} 18: 0)$ and MDA contents of maize silage tended to increase with the ensiling process. In contrast, unsaturated fatty acids (C18:1, C18:2 and C18:3) tended to decrease with the ensiling process. In the present study, the MDA value of yellow sweet clover increased up to 3.5-4 times with silage making according to herbage. An increase in MDA concentration with the ensiling of yellow sweet clover in the present study can result from the decomposition of the plant into fresh material during silage making, crushed-compression and acidic activity in anaerobic fermentation. The linoleic acid (C18:2) and alpha-linolenic acid (C18:3) of yellow sweet clover silage were negatively correlated with MDA of silage and herbage which was parallel with the results of Han and Zhou (2013). Elgersma et al. 
(2003) demonstrated that virtually all fatty acids in fresh grass are in the form of esterified fatty acids, whereas in silage, a large proportion is in the form of free fatty acids. Palmitic acid (C16:0) content of yellow sweet clover silage at the full flowering stage was grower than of herbage, which was similar to maize silage results of Han and Zhou (2013). The decrease in unsaturated fatty acids can be related to the increasing degradation of unsaturated fatty acids by lipid peroxidation in the plant. The increasing MCFA ratio in \% in total fatty acids of yellow sweet clover herbage and silage with plant growing can be related to flower ratio, leaf:stem ratio or plant metabolism changes.

\section{Conclusions}

The fact that the yellow sweet clover herbages at different phenological stages have similar in vitro digestibility for each period can be valuable for producers. While this plant is used as forage in ruminant rations, it should not be overlooked during the growth period of the plant. This legume forage plant is a quality forage rich in crude protein, energy, organic matter digestibility and alpha-linolenic acid. The ensiling of yellow sweet clover can be recommended to be found at a certain level of functional fatty acids, but there is also a disadvantage that enhances lipid peroxidation. For ideal silage acidity, it can be recommended to make silage at the vegetative and early flowering stages.

\section{Acknowledgments}

I would like to thank Ayşe Beren Kara for her assistance in collecting plant material and making silage.

\section{Conflict of interest}

The authors declare that there is no conflict of interest.

\section{References}

Allen O.N., Allen E.K., 1981. The Leguminosae: A Source Book of Characteristics, Uses and Nodulation. Madison, WI (USA)

Al Sherif E.A., 2009. Melilotus indicus (L.) All., a salt-tolerant wild leguminous herb with high potential for use as a forage crop in salt-affected soils. Flora 204, 737-746, https://doi. org/10.1016/j.flora.2008.10.004

Alonso V.A., Pereyra C.M., Keller L.A.M., Dalcero A.M., Rosa C.A.R., Chiacchiera S.M., Cavaglieri L.R., 2013. Fungi and mycotoxins in silage: an overview. J. Appl. Microbiol. 115, 637-643, https://doi.org/10.1111/jam.12178
Améndola-Massiotti R.D., González-Ortiz R., Miranda-Romero L.A., Burgueño-Ferreira J.A., Topete-Pelayo P., 2018. Ensiling alfalfa (Medicago sativa L.) and orchard grass (Dactylis glomerata L.) forage harvested at 08:00 or 14:00, without wilting or 1 or $2 \mathrm{~h}$ wilting and with or without use of bacterial inoculant. In: R.L. Edvan, E.M. Santos (Ediotors). Forage Groups. IntechOpen. London (UK), https://doi.org/10.5772/ intechopen.81509

AOAC International, 1995. Official Methods of Analysis of AOAC International. $16^{\text {th }}$ Edition. Arlington, VA (USA)

Ateş E., Seren O.A., 2020. Determination of forage yield and quality of blue melilot (Mellitus caeruleus (L.) Desr.) at different growth stages under Edirne ecological conditions. Ege Üniv. Ziraat Fak. Derg. 57, 111-117, https://doi.org/10.20289/ zfdergi.609079

Barnett A.J.G., 1951. The colorimetric determination of lactic acid in silage. Biochem. J. 49, 527-529, https://doi.org/10.1042/ bj0490527

Bernardes T.F., Gervásio J.R.S., De Morais G., Casagrande D.R., 2019. Technical note: a comparison of methods to determine pH in silages. 102, 9039-9042, https://doi.org/10.3168/ jds.2019-16553

Botsoglou N.A., Fletouris D.J., Papageorgious G.E., Vassilopoulos V.N., Mantis A.J., Trakatellis A.G., 1994. Rapid, sensitive, and specific thiobarbituric acid method for measuring lipid peroxidation in animal tissue, food, and feedstuff samples. J. Agric. Food Chem. 42, 1931-1937, https://doi.org/10.1021/ jf00045a019

Çaçan E., Aydın A., Başbağ M., 2015. Determination of quality features of some legume forage crops in Bingöl University Campus. Turk. J. Agric. Nat. Sci. 2, 105-111

Canbolat Ö., Karaman Ş., 2009. Comparison of in vitro gas production, organic matter digestibility, relative feed value and metabolizable energy contents of some legume forages. J. Agric. Sci. 15, 188-195

Cornara L., Xiao J., Burlando B., 2016. Therapeutic potential of temperate forage legumes: a Review. Crit. Rev. Food Sci. Nutr. 56, Suppl. 1, S149-S161, https://doi.org/10.1080/1040 8398.2015.1038378

DaCosta M., Huang B., 2007. Changes in antioxidant enzyme activities and lipid peroxidation for bentgrass species in response to drought stress. J. Am. Soc. Hortic. Sci. 132, 319-326, https:// doi.org/10.21273/JASHS.132.3.319

Dierking R.M., Kallenbach R.L., Roberts C.A., 2010. Fatty acid profiles of orchardgrass, tall fescue, perennial ryegrass, and alfalfa. Crop Sci. 50, 391-402, https://doi.org/10.2135/ cropsci2008.12.0741

Dumlu Z., Tan M., 2009. Determination of silage value of some legumes and mixtures in erzurum conditions (in Turkish) Atatürk Üniv. Ziraat Fak. Derg. 40, 15-21

Ehlert K., 2020. Yellow sweet clover: information and management. https://extension.sdstate.edu/yellow-sweet-clover-informationand-management (accessed at 01.05.2021)

Elgersma A., Ellen G., van der Horst H., Muuse B.G., Boer H., Tamminga S., 2003. Comparison of the fatty acid composition of fresh and ensiled perennial ryegrass (Lolium perenne L.), affected by cultivar and regrowth interval. Anim. Feed Sci. Technol. 108, 191-205, https://doi.org/10.1016/S03778401(03)00134-2

Ersahince A.C., Kara K., 2017. Nutrient composition and in vitro digestion parameters of Jerusalem artichoke (Helianthus tuberosus L.) herbage at different maturity stages in horse and ruminant. J. Anim. Feed Sci. 26, 213-225, https://doi. org/10.22358/jafs/76477/2017 
Glasser F., Doreau M., Maxin G., Baumont R., 2013. Fat and fatty acid content and composition of forages: a meta-analysis. Anim. Feed Sci. Technol. 185, 19-34, https://doi.org/10.1016/j. anifeedsci.2013.06.010

Han L., Zhou H., 2013. Effects of ensiling processes and antioxidants on fatty acid concentrations and compositions in corn silages. J. Anim. Sci. Biotechnol. 4, 48, https://doi.org/10.1186/20491891-4-48

Jasicka-Misiak I., Makowicz E., Stanek N., 2017. Polish yellow sweet clover (Melilotus officinalis L.) honey, chromatographic fingerprints, and chemical markers. Molecules 22, 138, https://doi.org/10.3390/molecules22010138

Kara K., 2015. In vitro methane production and quality of corn silage treated with maleic acid. Ital. J. Anim. Sci. 14, 3994, https:// doi.org/10.4081/ijas.2015.3994

Kara K., 2020. Milk urea nitrogen and milk fatty acid compositions in dairy cows with subacute ruminal acidosis. Vet. Med. Czech 65, 336-345, https://doi.org/10.17221/51/2020-VETMED

Kara K., Aktuğ E., Özkaya S., 2016. Ruminal digestibility, microbial count, volatile fatty acids and gas kinetics of alternative forage sources for arid and semi-arid areas as in vitro. Ital. J. Anim. Sci. 15, 673-680, https://doi.org/10.1080/182805 1X.2016.1249420

Kara K., Güçlü B.K., Baytok E., 2015. Comparison of nutrient composition and anti-methanogenic properties of different Rosaceae species. J. Anim. Feed Sci. 24, 308-314, https:// doi.org/10.22358/jafs/65613/2015

Kara K., Ozkaya S., Baytok E., Guclu B.K., Aktug E., Erbas S., 2018. Effect of phenological stage on nutrient composition, in vitro fermentation and gas production kinetics of Plantago lanceolate herbage. Vet. Med. 63, 251-260, https://doi. org/10.17221/2/2017-VETMED

Klebesadel L.J., 1992. Morphological, Physiological, and Winterhardiness Comparisons Among Latitudinal Ecotypes of Biennial Sweetclover (Melilotus Species) in Subarctic Alaska. Bulletin 91, http://hdl.handle.net/11122/1294

Lacey J., 1991. Natural occurrence of mycotoxins in growing and conserved forage crops. In: J.E. Smith, R. Henderson (Editors). Mycotoxins and Animal Foods. CRC Press. Boca Raton, FL (USA), pp. 363-397

Luo K., Di H.Y., Zhang J.Y., Wang Y.R., Li Z.Q., 2014. Preliminary evaluation of agronomy and quality traits of nineteen Melilotus accessions. Pratacult. Sci. 8, 2125-2134, https:// doi.org/10.11829/j.issn.1001-0629.2013-0455

Menke K.H., Raab L., Salewski A., Steingass H., Fritz D., Schneider W., 1979. The estimation of the digestibility and metabolizable energy content of ruminant feedstuffs from the gas production when they are incubated with rumen liquor in vitro. J.Agric. Sci. 93, 217-222, https://doi.org/10.1017/S0021859600086305

Menke K.H., Steingass H., 1988. Estimation of the energetic feed value obtained from chemical analysis and in vitro gas production using rumen fluid. Anim. Res. Develop. 28, 7-55

Mir P.S., Bittman S., Hunt D., Entz T., Yip B., 2006. Lipid content and fatty acid composition of grasses sampled on different dates through the early part of the growing season. Can. J. Anim. Sci. 86, 279-290, https://doi.org/10.4141/A05-050

National Academies of Sciences, Engineering, and Medicine, 2016. Nutrient Requirements of Beef Cattle. $8^{\text {th }}$ Revised Edition. The National Academies Press. Washington, DC (USA), https://doi.org/10.17226/19014
NRC (National Research Council), 2001. Nutrient Requirements of Dairy Cattle. $7^{\text {th }}$ Revised Edition. The National Academies Press. Washington, DC (USA), https://doi.org/10.17226/9825

Ogle D., St, John L., Tilley D., 2008. Plant Guide for yellow sweetclover (Melilotus officinalis (L.) Lam.) and white sweetclover (M. alba Medik). USDA-Natural Resources Conservation Service, Idaho Plant Materials Center. Aberdeen, ID (USA). 83210, https://www.nrcs.usda.gov/Internet/FSE_DOCUMENTS/ nrcs144p2_043029.pdf

Prasad T.K., 1996. Mechanisms of chilling-induced oxidative stress injury and tolerance in developing maize seedlings: changes in antioxidant system, oxidation of proteins and lipids, and protease activities. Plant J. 10, 1017-1026, https://doi. org/10.1046/j.1365-313X.1996.10061017.x

Szumacher-Strabel M., Cieślak A., 2012. Dietary possibilities to mitigate rumen methane and ammonia production. In: G. Liu (Editor). Greenhouse Gases: Capturing, Utilisation and Reduction. IntechOpen. London (UK), https://doi. org/10.5772/32105

Talbi S., Romero-Puertas M.C., Hernández A., Terrón L., Ferchichi A., Sandalio L.M., 2015. Drought tolerance in a Saharian plant Oudneya africana: role of antioxidant defences. Environ. Exp. Bot. 111, 114-126, https://doi.org/10.1016/j. envexpbot.2014.11.004

Tekin M., Kara K., 2020. The forage quality and the in vitro ruminal digestibility, gas production, organic acids, and some estimated digestion parameters of tomato herbage silage with molasses and barley. Turk. J. Vet. Anim. Sci. 44, 201-213, https://doi.org/10.3906/vet-1908-47

Thompson J.E., Froese C.D., Madey E., Smith M.D., Hong Y., 1998. Lipid metabolism during plant senescence. Prog. Lipid Res. 37, 119-141, https://doi.org/10.1016/S0163-7827(98)00006-X

Turkington R.A., Cavers P.B., Rempel E., 1978. The biology of Canadian weeds. 29. Melilotus alba Desr. and M. officinalis (L.) Lam. Can. J. Plant Sci. 58, 523-537, https://doi. org/10.4141/cjps78-078

Van Ranst G., Fievez V., Vandewalle M., De Riek J., Van Bockstaele E., 2009. Influence of herbage species, cultivar and cutting date on fatty acid composition of herbage and lipid metabolism during ensiling. Grass Forage Sci. 64, 196-207, https://doi. org/10.1111/j.1365-2494.2009.00686.x

Vanhatalo A., Kuoppala K., Toivonen V., Shingfield K.J., 2007. Effects of forage species and stage of maturity on bovine milk fatty acid composition. Eur. J. Lipid. Sci. Technol. 109, 856-867, https://doi.org/10.1002/ejlt.200700023

Van-Soest P.J., Robertson J.B., Lewis B.A., 1991. Methods for dietary fiber, neutral detergent fiber and non- starch polysaccharides in relation to animal nutrition. J. Dairy Sci. 74, 3583-3597, https://doi.org/10.3168/jds.S0022-0302(91)78551-2

Wang J., Wu W., Wang X., Wang M., Wu F., 2015. An affective GC method for the determination of the fatty acid composition in silkworm pupae oil using a two-step methylation process. J. Serbian Chem. Soc. 80, 9-20, https://doi.org/10.2298/ JSC140401073W

Yisehak K., 2008. Effect of seed proportions of Rhodes grass (Chloris gayana) and white sweet clover (Melilotus alba) at sowing on agronomic characteristics and nutritional quality. Livest. Res. Rural Develop. 20, 28 